\title{
Studi Pengaruh Suhu Dan Ketebalan Irisan Terhadap Kadar Air, Laju Pengeringan Dan Karakteristik Fisik Ubi Kayu Dan Ubi Jalar
}

\author{
Adhit Mardita Yando dan Vita Paramita* \\ Program Studi Teknik Kimia, Departemen Teknologi Industri, Sekolah Vokasi, Universitas Diponegoro \\ Jl. Prof. Soedarto, Tembalang, Kota Semarang, Jawa Tengah 50275, Indonesia \\ Email : vita.paramita@gmail.com
}

\begin{abstract}
Abstrak
Pengujian kadar air, laju pengeringan dan organoleptik dilakukan terhadap ubi kayu dan ubi jalar menggunakan oven Memmert type UN 110 dengan variabel suhu 70,90 dan $120^{\circ} \mathrm{C}$ serta variabel ketebalan 1 $\mathrm{mm}, 2 \mathrm{~mm}, 3 \mathrm{~mm}, 4 \mathrm{~mm}$ dan $5 \mathrm{~mm}$. Kadar air ubi kayu terbaik pada suhu $90^{\circ} \mathrm{C}$ yaitu $54.367 \%$ dengan ketebalan $4 \mathrm{~mm}$ serta hasil laju pengeringan maksimalnya pada suhu $120{ }^{\circ} \mathrm{C}$ yaitu $0.091 \mathrm{gram} / \mathrm{menit}$ dengan ketebalan $5 \mathrm{~mm}$. Hasil uji organoleptik menunjukkan semua bahan pada suhu $120{ }^{\circ} \mathrm{C}$ mengalami penghitaman namun bahan pada suhu $70{ }^{\circ} \mathrm{C}$ dan $90{ }^{\circ} \mathrm{C}$ dengan tebal 3, 4 dan $5 \mathrm{~mm}$ tidak mengalami penghitaman. Sedangkan pada ubi jalar, kadar air terbaik pada suhu $70{ }^{\circ} \mathrm{C}$ yaitu $66.397 \%$ dengan ketebalan 1 $\mathrm{mm}$ serta hasil laju pengeringan maksimalnya pada suhu $120^{\circ} \mathrm{C}$ yaitu $0.077 \mathrm{gram} / \mathrm{menit}$ dengan ketebalan 5 $\mathrm{mm}$. Hasil uji organoleptik memperlihatkan semua bahan mengalami penghitaman dengan bahan yang paling hitam dialami pada bahan dengan perlakuan suhu $90^{\circ} \mathrm{C}$ dengan ketebalan $1 \mathrm{~mm}$.
\end{abstract}

Kata kunci: Kadar air, laju pengeringan, organoleptic, ubi kayu, ubi jalar

\author{
Abstract \\ Studies Effect Of Temperature And Thickness Of Slices To Water Content, Drying Rate And Physical \\ Characteristic Cassava And Sweet Potatoes
}

Determine of moisture content, drying rate and organoleptic was done on cassava and sweet potatoes using Memmert type $110 \mathrm{UN}$ oven with temperature variable 70,90 and $120{ }^{\circ} \mathrm{C}$ and variable thickness $1 \mathrm{~mm}, 2 \mathrm{~mm}$, $3 \mathrm{~mm}, 4 \mathrm{~mm}$ and $5 \mathrm{~mm}$. The best cassava moisture content at $90^{\circ} \mathrm{C}$ have value $54.367 \%$ with a thickness of 4 $\mathrm{mm}$ and the maximum drying rate at $120^{\circ} \mathrm{C}$ have value $0.091 \mathrm{gram} / \mathrm{min}$ with a thickness of $5 \mathrm{~mm}$. The result of an organoleptic test shown all the materials at $120^{\circ} \mathrm{C}$ had blackening but the material at $70^{\circ} \mathrm{C}$ and $90^{\circ} \mathrm{C}$ with thickness 3, 4 and $5 \mathrm{~mm}$ did not experience blackening. While in sweet potato, the best moisture content at 70 ${ }^{\circ} \mathrm{C}$ have value $66.397 \%$ with a thickness of $1 \mathrm{~mm}$ and the maximum drying rate at $120{ }^{\circ} \mathrm{C}$ have value 0.077 $\mathrm{gram} / \mathrm{min}$ with a thickness of $5 \mathrm{~mm}$. The result of an organoleptic test showed all the ingredients were blackened with the blackest material experienced by the material with temperature treatment $90{ }^{\circ} \mathrm{C}$ with thickness $1 \mathrm{~mm}$.

Keyword: moisture content, drying rate, organoleptic, cassava, sweet potato

\section{PENDAHULUAN}

Ubi kayu merupakan umbi akar dari tanaman pangan berupa perdu yang dikenal dengan nama lain ubi kayu, ketela pohon atau singkong. Ubi kayu mudah ditanam dan budidayakan, dapat ditanam di lahan yang kurang subur, risiko gagal panen $5 \%$, dan tidak mudah terserang hama. Dengan perkembangan teknologi, ubi kayu dijadikan bahan dasar pada 
industri makanan dan bahan baku industri pakan. Selain itu, digunakan pula dalam industri obat obatan (Rukmana, 1997).

Sedangkan Ubi jalar pertama kali diperkenalkan di luar wilayah Andes empat abad yang lalu dan telah menjadi bagian integral dari sebagian besar masakan dunia (Garayo and Moreira, 2002). Tiba di Afrika sekitar 20 abad. Belakangan ini diproduksi secara terus-menerus, meningkat 2 juta ton pada tahun 1960 dan menjadi rekor pada tahun 2007 dengan produksi 16,7 juta ton. Ubi jalar memiliki periode pertumbuhan terpendek dari semua tanaman umbi akar. Banyak varietas ubi jalar yang tersedia mulai dari warna daging oranye hingga ungu. Ubi jalar tahan kekeringan dan relatif bebas dari penyakit (Kroikida et al., 2001). Ubi kayu dan ubi jalar hanya dapat bertahan 2-3 hari dalam penyimpanan suhu kamar sebelum membusuk, penanganan pasca panen dibutuhkan untuk memperpanjang waktu simpan bahan serta menjaga kualitas bahan. Penanganan pasca panen bertujuan untuk mempertahankan mutu produk dan meningkatkan nilai tambah. Agar dapat memperpanjang masa simpan produk, diperlukan proses pengawetan. Salah satu cara yang dapat dilakukan adalah dengan melakukan proses pengeringan (Rukmana, 1997). Menurut Suharto (1991), pengawetan bahan (pangan) pada dasarnya adalah berada dalam dua alternatif yaitu yang pertama menghambat pertumbuhan enzimenzim dan aktivitas/pertumbuhan microba dengan menurunkan suhunya hingga dibawah $0^{\circ} \mathrm{C}$ dan yang kedua adalah menurunkan kandungan air dari bahan (pangan) sehingga kurang/tidak memberi kesempatan untuk tumbuh/hidupnya mikroba dengan pengeringan atau penguapan kandungan air yang ada didalam maupun dipermukaan bahan/pangan, sehingga mencapai kondisi tertentu.

Pengeringan adalah suatu cara untuk mengurangi kadar air suatu bahan, sehingga diperoleh hasil akhir yang kering. Pengeringan ini bertujuan untuk memperpanjang masa simpan bahan pangan (Koswara, 2013). Rohanah (2006) menyatakan pada proses pengeringan selalu diinginkan kecepatan pengeringan yang maksimal. Oleh karena itu perlu dilakukan usahausaha untuk mempercepat pindah panas dan pindah massa (pindah massa dalam hal ini adalah perpindahan air keluar dari bahan yang dikeringkan dalam proses pengeringan tersebut). Ada beberapa faktor yang perlu diperhatikan untuk memperoleh kecepatan pengeringan yang maksimum, yaitu (a) luas permukaan bahan,(b) suhu, (c) kecepatan udara, (d) kelembaban udara $(\mathrm{RH})$, (e) tekanan atmosfir dan vakum, dan (f) waktu.

Pengering buatan atau mekanis merupakan suatu alat yang dirancang sebagai alternatif dalam mengatasi proses pengeringan bahan. Pengering buatan memiliki beberapa kelebihan dibandingkan penjemuran matahari atau konvensional, misalnya tidak bergantung pada panas matahari dan pengaruh cuaca, tidak memakai tempat atau lokasi yang luas, kapasitas dapat dipilih sesuai keinginan, tidak memerlukan tenaga kerja yang banyak, dan selain itu dapat meningkatkan kualitas hasil pengeringan serta dapat mempersingkat waktu pengeringan. Sumber energi pada pengeringan mekanis yang diuji pada penelitian ini adalah udara panas yang dihasilkan dari heater yang dialirkan ke rak pengering yang mana ditempatkannya bahan yang akan dikeringkan. Udara panas yang dihasilkan sesungguhnya berasal dari elemen pemanas (heater) yang dialirkan menggunakan dorongan alat penghembus udara (kipas). Pada pengering mekanis memiliki tiga level daya listrik yang dapat dipilih untuk menghasilkan suhu udara pengering yang diinginkan dari elemen pemanas (heater). Pemilihan level suhu akan mempengaruhi seberapa lama bahan akan kering jika kecepatan aliran udara panas sudah ditentukan (Koswara, 2013).

\section{METODOLOGI}

Bahan yang digunakan berupa ubi kayu dan ubi jalar dengan ketebalan irisan $1 \mathrm{~mm}, 2 \mathrm{~mm}$, $3 \mathrm{~mm}, 4 \mathrm{~mm}$ dan $5 \mathrm{~mm}$. Peralatan yang digunakan meliputi oven Memmert type UN 110 (Memmert $\mathrm{GmbH}+$ Co. KG, Deutschland) dengan kapasitas 108 liter, wadah (nampan), desikator dan neraca digital.

Pada penelitian ini dilakukan pengeringan terhadap ubi kayu dan ubi jalar dengan variable tebal irisan yaitu $1 \mathrm{~mm}, 2 \mathrm{~mm}, 3 \mathrm{~mm}, 4 \mathrm{~mm}$ dan 5 $\mathrm{mm}$ dan dengan variable suhu 70,90 dan $120^{\circ} \mathrm{C}$. penimbangan dilakukan tiap 15 menit. 
Penelitian dilakukan untuk menganalisa kadar air bahan dan laju pengeringan bahan dengan metode gravimetri. Kadar air bahan dihitung sebagai berikut (Yahya et al., 2016) :

$M_{c}=\frac{M_{w}}{M_{w}+M_{d}}$

di mana $M_{w}$ adalah massa air $(\mathrm{kg})$, dan $M_{d}$ adalah massa kering $(\mathrm{kg})$. Laju pengeringan adalah massa air menguap dari produk per satuan waktu dan dihitung sebagai berikut (Yahya et al., 2016) :

$\dot{\mathrm{m}}_{\text {water }}=\frac{m_{\text {water }}}{\dot{\mathrm{t}}}$

di mana $\mathrm{m}_{\text {air }}$ adalah massa air yang menguap $(\mathrm{kg})$, dan $t$ adalah waktu pemanasan. Massa air yang menguap $\left(\mathrm{m}_{\mathrm{air}}\right)$ dari produk basah bisa dihitung sebagai berikut (Yahya et al., 2016) :

$m_{\text {water }}=\frac{m_{p}\left(M_{i}-M_{f}\right)}{100+M_{f}}$

di mana $m_{p}$ adalah massa awal produk $(\mathrm{kg}), M_{i}$ adalah kadar air awal wet basis (\%) dan $\mathrm{M}_{\mathrm{f}}$ adalah kadar air akhir wet basis (\%).

\section{HASIL DAN PEMBAHASAN}

Gambar 1 menunjukan hasil pengamatan kadar air ubi jalar terhadap waktu pengeringan dengan ketebalan $1 \mathrm{~mm}, 2 \mathrm{~mm}, 3 \mathrm{~mm}, 4 \mathrm{~mm}$ dan $5 \mathrm{~mm}$ dengan menggunakan oven. Masingmasing ketebalan tersebut dilakukan pemanasan pada suhu yang berbeda yaitu 70,90 dan $120^{\circ} \mathrm{C}$. kadar air rata-rata dan waktu pengeringan yang didapat yaitu $53.255 \%$ dengan waktu 90 menit pada suhu $120^{\circ} \mathrm{C}, 53.899 \%$ dengan waktu 165 menit pada suhu $90{ }^{\circ} \mathrm{C}$ dan $53.124 \%$ dengan waktu 195 menit pada suhu $70{ }^{\circ} \mathrm{C}$. Pada setiap suhu tidak terjadi perbedaan kadar air yang begitu jauh yaitu kisara 53-54\% begitupun dengan kadar air yang dihasilkan tiap ketebalan yang memiliki kadar air kisaran 53-54\%. Perbedaan terdapat pada lamanya waktu pengeringan. Pada suhu 120 ${ }^{\circ} \mathrm{C}$ (a) membutuhkan waktu pengeringan yang paling cepat yaitu 90 menit dan pada waku $70{ }^{\circ} \mathrm{C}$ (c) membutuhkan waktu pengeringan paling lama yaitu 195 menit.

Yahya et al. (2016) melakukan penelitian yang sama yaitu dengan bahan ubi kayu tebal irisan 2-3 mm dengan suhu $45{ }^{\circ} \mathrm{C}$. kadar air yang didapat yaitu $61 \%$ dengan waktu pengeringan 9 jam menggunakan solar dryer. Jika dibandingkan dengan penelitian yang menggunakan suhu pengeringan 70,90 dan $120{ }^{\circ} \mathrm{C}$ terdapat perbedaan yang sangat jauh pada waktu pengeringan antar pengeringan dengan suhu 45 ${ }^{\circ} \mathrm{C}$ (Yahya et al., 2016) dan suhu $70,90,120^{\circ} \mathrm{C}$. hal tersebut terjadi karena alat yang digunakan pada kedua penelitian ini berbeda sehingga memiliki

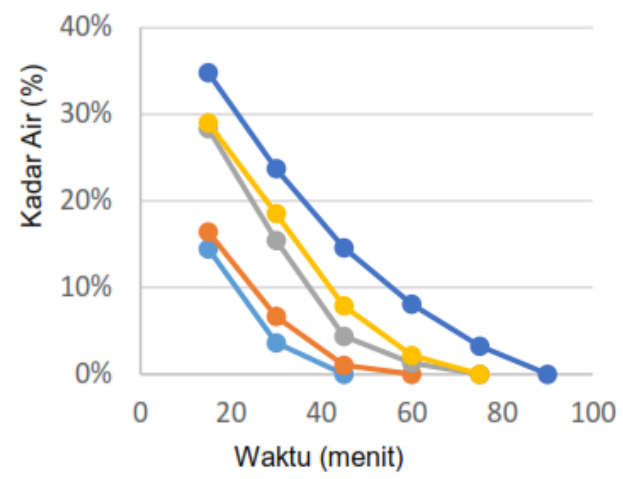

(a)

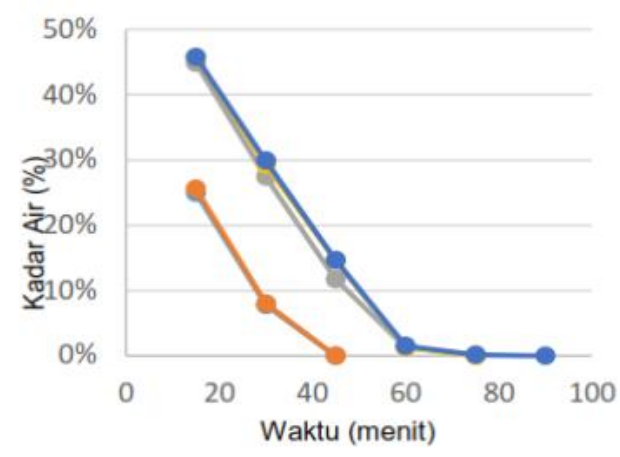

(b)

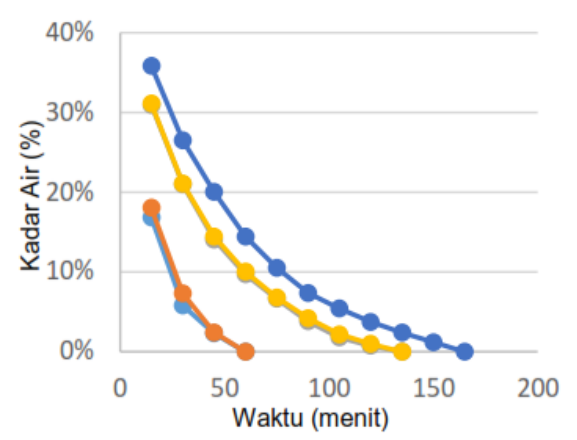

(c)

Gambar 1. Kadar Air Ubi Kayu pada Suhu (a) 70 ${ }^{\circ} \mathrm{C}$, (b) $90^{\circ} \mathrm{C}$ dan (c) $120^{\circ} \mathrm{C}$. Keterangan : -, $1 \mathrm{~mm} ;-, 2 \mathrm{~mm} ;-, 3 \mathrm{~mm} ;-, 4 \mathrm{~mm}$ dan,$- 5 \mathrm{~mm}$. 
efesiensi yang berbeda pula. Untuk kadar air tidak mengalami perbedaan yang jauh yaitu memiliki perbedaan sekitar 5\%. Hal tersebut terjadi kemungkinan karena bahan yang digunakan tidak segar sehingga telah mengalami kehilangan kadar air saat penyimpanan.

Gambar 2 menunjukan hasil pengamatan kadar air ubi jalar terhadap waktu pengeringan dengan ketebalan $1 \mathrm{~mm}, 2 \mathrm{~mm}, 3 \mathrm{~mm}, 4 \mathrm{~mm}$ dan $5 \mathrm{~mm}$ dengan menggunakan oven. Masingmasing ketebalan tersebut dilakukan pemanasan pada suhu yang berbeda yaitu $120^{\circ} \mathrm{C}(\mathrm{a}), 90^{\circ} \mathrm{C}(\mathrm{b})$ dan $70^{\circ} \mathrm{C}$ (c), dengan perbedaan suhu tersebut kadar air rata-rata yang dihasilkan dari masingmasing suhu yang berbeda didapatkan hasil kadar air rata-rata yang tidak begitu berbeda yaitu $65.330 \%, 65.303 \%$ dan $64.962 \%$. perbedaan dari tiga variabel suhu tersebut terdapat pada lamanya waktu pengeringan yang dibutuhkan untuk menghilangkan kandungan air dalam bahan. Pada suhu $120{ }^{\circ} \mathrm{C}$ dengan ketebalan $5 \mathrm{~mm}$ hanya membutuhkan waktu pengeringan 90 menit, pada suhu $90{ }^{\circ} \mathrm{C}$ dengan ketebalan $5 \mathrm{~mm}$ membutuhkan waktu pengeringan 165 menit dan pada suhu $70{ }^{\circ} \mathrm{C}$ dengan ketebalan $5 \mathrm{~mm}$ membutuhkan waktu pengeringan 195 menit.

Veleșcu (2013) melakukan penelitian yang sama yaitu menggunakan ubi jalar namun dengan suhu yang berbeda yaitu 50,60 dan $70^{\circ} \mathrm{C}$ dengan tebal irisan $5 \mathrm{~mm}$ dengan menggunakan tray dryer. Dari penelitian tersebut hasil kadar air dan waktu pengeringan yang didapat yaitu $80.99 \%$ dengan waktu pengeringan 420 menit, $79.72 \%$ dengan wakru pengeringan 390 menit dan $79.31 \%$ dengan waktu pengeringan 360 menit. Terlihat bahwa terjadi perbedaan hasil kadar air dengan penelitian yang menggunakan suhu 70, 90 dan $120^{\circ} \mathrm{C}$. seharusnya kadar air yang dihasilkan tidak jauh berbeda. Perbedaan yang cukup besar ini bisa terjadi karena ubi jalar yang praktikan gunakan bisa jadi bahan tidak segar sehingga ada sebagian kadar air yang telah hilang sebelum dilakukannya pengujian. Tetapi pada waktu pengeringan mengalami kesamaan yaitu, semakin tinggi suhu yang digunakan untuk pengeringan maka semakin sedikit waktu pengeringan yang diperlukan.

Gambar 3 menunjukan hubungan laju pengeringan ubi kayu terhadap waktu pengeringan dengan ketebalan irisan $1 \mathrm{~mm}, 2$ $\mathrm{mm}, 3 \mathrm{~mm}, 4 \mathrm{~mm}$ dan $5 \mathrm{~mm}$ dengan menggunakan oven. Pengeringan dilakukan dengan tiga suhu berbeda terhadap lima irisan tersebut yaitu dengan suhu 70,90 dan $120^{\circ} \mathrm{C}$. laju pegeringan maksimum pada suhu pengeringan

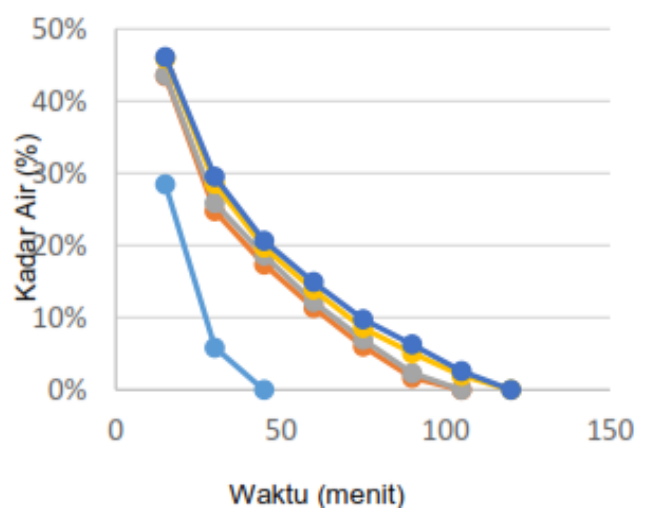

(a)

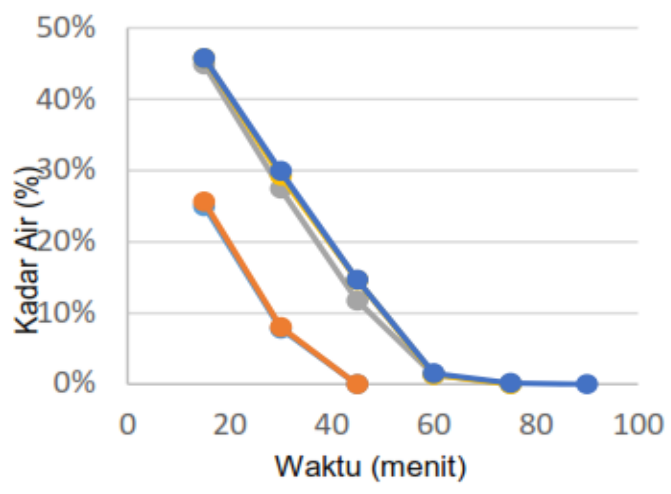

(b)

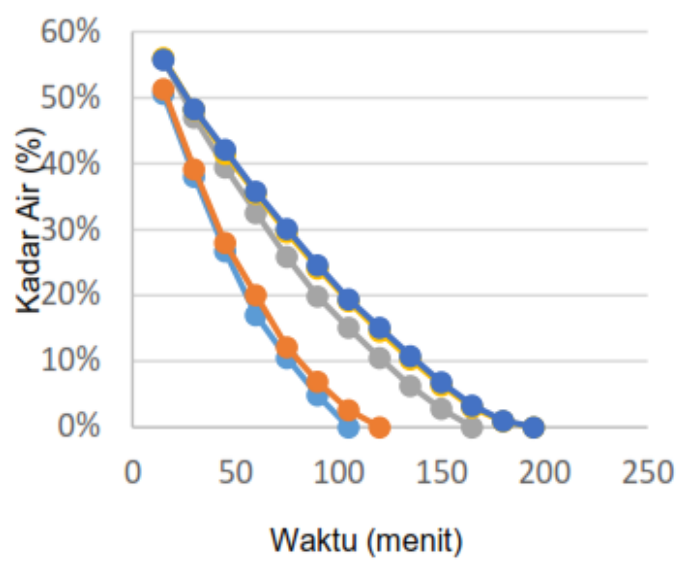

(c)

Gambar 2. Kadar Air Ubi Jalar pada suhu (a) 70 ${ }^{\circ} \mathrm{C}$, (b) $90{ }^{\circ} \mathrm{C}$ dan (c) $120{ }^{\circ} \mathrm{C}$. Keterangan : -, $1 \mathrm{~mm} ;-, 2 \mathrm{~mm} ;-, 3$ $\mathrm{mm} ;-, 4 \mathrm{~mm}$ dan,$- 5 \mathrm{~mm}$. 


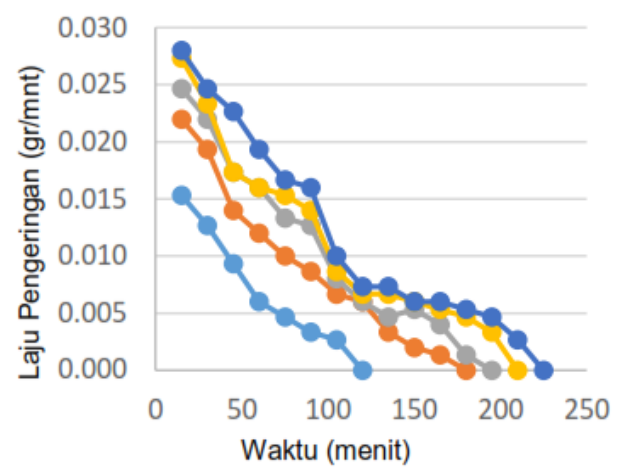

(a)

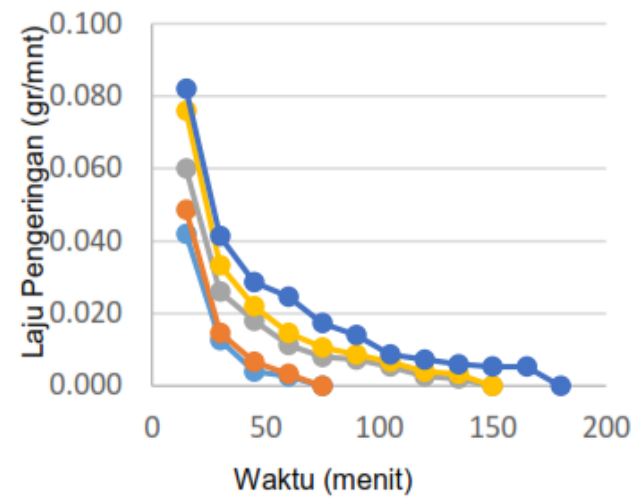

(b)

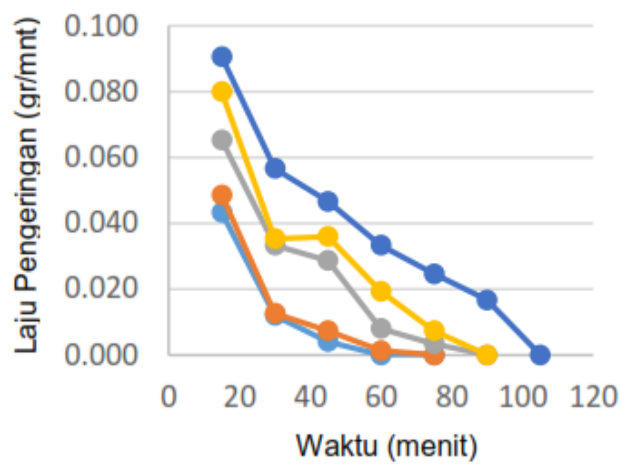

(c)

Gambar 3. Laju Pengeringan Ubi Kayu pada Suhu (a) $70^{\circ} \mathrm{C}$, (b) $90^{\circ} \mathrm{C}$ dan (c) $120^{\circ} \mathrm{C}$. Keterangan :,$- 1 \mathrm{~mm} ;-, 2 \mathrm{~mm} ;-, 3$ $\mathrm{mm} ;-, 4 \mathrm{~mm}$ dan,$- 5 \mathrm{~mm}$.

$120{ }^{\circ} \mathrm{C}$ yaitu 0.091 gram/menit. Pada grafik suhu $120{ }^{\circ} \mathrm{C}$ (a) terlihat laju pengeringan sangat cepat, pada suhu $90^{\circ} \mathrm{C}$ (b) laju pengeringan cukup cepat dan pada suhu $70{ }^{\circ} \mathrm{C}$ (c) laju pengeringan sangat lambat sehingga waktu yang dibutuhkan untuk mengeringkan lama.

Yahya et al. (2016) juga melakukan penelitian laju pengeringan terhadap dengan suhu $45{ }^{\circ} \mathrm{C}$ dengan menggunakan solar dryer. Hasil laju pengeringan maksimal yaitu $0.15 \mathrm{~kg} / \mathrm{jam}$ pada menit ke 120 menit dengan jumlah bahan $30.8 \mathrm{~kg}$. Dengan membandingkan penelitian pada suhu 70,90 dan $120^{\circ} \mathrm{C}$ terhadap suhu $45^{\circ} \mathrm{C}$ (Yahya et al, 2015), terlihat bahwa pada suhu 45 ${ }^{\circ} \mathrm{C}$ mengalami laju pengeringan yang sangat cepat. Hal tersebut karena bahan yang digunakan pada suhu $45{ }^{\circ} \mathrm{C}$ jauh lebih banyak dari pada bahan yang digunakan pada suhu 70, 90 dan 120 ${ }^{\circ} \mathrm{C}$ yang hanya berkisar 1-4 gram.

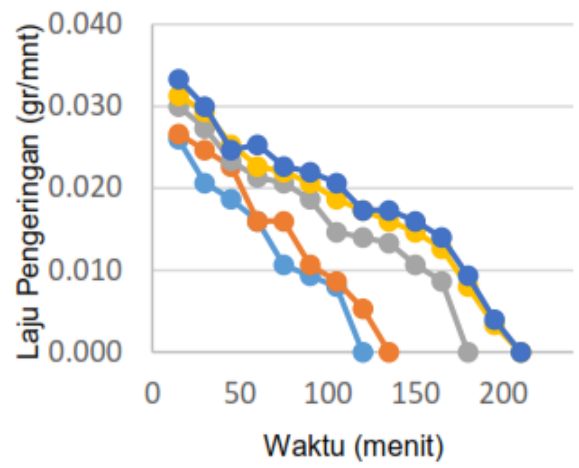

(a)

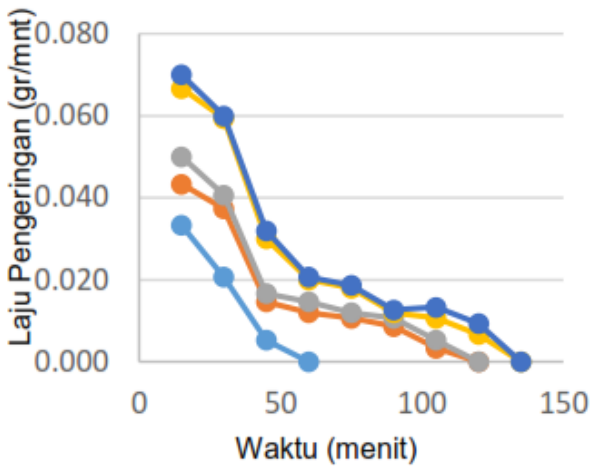

(b)

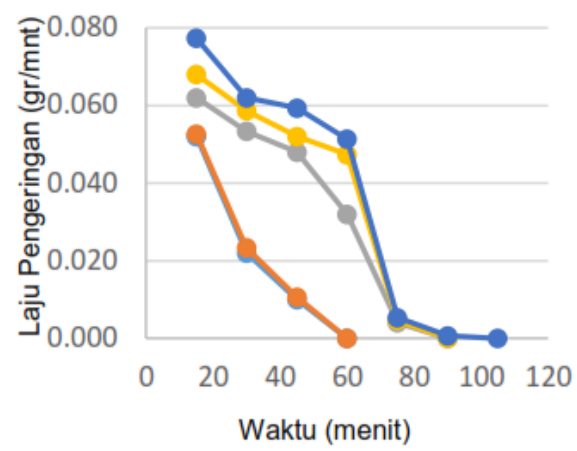

(c)

Gambar 4. Laju Pengeringan Ubi Jalar pada Suhu (a) $70{ }^{\circ} \mathrm{C}$, (b) $90{ }^{\circ} \mathrm{C}$ dan (c) $120{ }^{\circ} \mathrm{C}$. Keterangan :,$- 1 \mathrm{~mm} ;-, 2 \mathrm{~mm} ;-, 3$ $\mathrm{mm} ;-, 4 \mathrm{~mm}$ dan,$- 5 \mathrm{~mm}$. 
Gambar 4 menunjukan hubungan laju pengeringan ubi jalar terhadap waktu pengeringan dengan ketebalan irisan $1 \mathrm{~mm}, 2$ $\mathrm{mm}, 3 \mathrm{~mm}, 4 \mathrm{~mm}$ dan $5 \mathrm{~mm}$ dengan menggunakan oven. Pengeringan dilakukan dengan tiga suhu berbeda terhadap lima irisan tersebut yaitu dengan suhu 70,90 dan $120^{\circ} \mathrm{C}$. laju pengeringan maksimum yang didapat yaitu 0.077 gram/menit pada suhu $120^{\circ} \mathrm{C}$, $0.07 \mathrm{gram} / \mathrm{menit}$ pada suhu $90^{\circ} \mathrm{C}$ dan $0.033 \mathrm{gram} / \mathrm{menit}$ pada suhu $70{ }^{\circ} \mathrm{C}$. Perbedaan dari variable suhu tersebut dapat dilihat pada grafik, pada suhu $120^{\circ} \mathrm{C}$ grafik (a) menunjukan penurunan drastis dari menit ke 15 sampai menit ke 135, pada suhu 90 grafik (b) menunjukan penurunan yang tidak begitu drastic dri menit ke 15 sampai menit ke 210 dan pada suhu 70 grafik (c) memperlihatkan laju pengeringan begitu lambat sehingga membutuhkan waktu untuk mengeringkan bahan.

Veleșcu (2013) meneliti laju pengeringan ubi jalar irisan $5 \mathrm{~mm}$ dengan perbedaan suhu 50, 60 dan $70{ }^{\circ} \mathrm{C}$ dengan menggunakan tray dryer. laju pengeringan maksimal didapat yaitu 20.29\%/jam, 18,59\%/jam dan 18,85\%/jam. Jika dibandingkan dengan penelitian variable suhu 70 ${ }^{\circ} \mathrm{C}, 90^{\circ} \mathrm{C}$ dan $120^{\circ} \mathrm{C}$, terdapat kesamaan yaitu semakin tinggi suhu maka semakin cepat laju pengeringan yang didapat.

Tabel 1. Uji Organoleptik Ubi Kayu

\begin{tabular}{cccccc}
\hline \multirow{2}{*}{ Suhu $\left({ }^{\circ} \mathrm{C}\right)$} & \multicolumn{5}{c}{ Tebal $(\mathrm{mm})$} \\
\cline { 2 - 6 } & 1 & 2 & 3 & 4 & 5 \\
\hline 70 & $2 \mathrm{~b}$ & $2 \mathrm{~b}$ & $2 \mathrm{c}$ & $2 \mathrm{c}$ & $2 \mathrm{c}$ \\
90 & $2 \mathrm{~b}$ & $2 \mathrm{~b}$ & $2 \mathrm{c}$ & $2 \mathrm{c}$ & $2 \mathrm{c}$ \\
120 & $1 \mathrm{~b}$ & $2 \mathrm{~b}$ & $2 \mathrm{~b}$ & $2 \mathrm{~b}$ & $2 \mathrm{~b}$ \\
\hline
\end{tabular}

Tabel 2. Uji Organolpetik Ubi Jalar

\begin{tabular}{cccccc}
\hline \multirow{2}{*}{ Suhu $\left({ }^{\circ} \mathrm{C}\right)$} & \multicolumn{5}{c}{ Tebal $(\mathrm{mm})$} \\
\cline { 2 - 6 } & 1 & 2 & 3 & 4 & 5 \\
\hline 70 & $2 \mathrm{~b}$ & $2 \mathrm{~b}$ & $2 \mathrm{~b}$ & $2 \mathrm{~b}$ & $2 \mathrm{~b}$ \\
90 & $1 \mathrm{a}$ & $1 \mathrm{a}$ & $1 \mathrm{a}$ & $1 \mathrm{a}$ & $1 \mathrm{a}$ \\
120 & $1 \mathrm{a}$ & $1 \mathrm{a}$ & $2 \mathrm{~b}$ & $2 \mathrm{~b}$ & $2 \mathrm{~b}$ \\
\hline
\end{tabular}

Keterangan:

Struktur : $1=$ sangat keriput

2 = sedikit keriput

3 = tidak keriput

Warna: $\quad \mathrm{a}=$ hitam

$\mathrm{b}=$ sedikit hitam

$\mathrm{c}=$ putih
Tabel 1 memperlihatkan uji organoleptik ubi kayu dengan perbedaan suhu 70, 90 dan 120 ${ }^{\circ} \mathrm{C}$ dan dengan ketebalan $1 \mathrm{~mm}, 2 \mathrm{~mm}, 3 \mathrm{~mm}, 4$ $\mathrm{mm}$ dan $5 \mathrm{~mm}$. Pada suhu $70{ }^{\circ} \mathrm{C}$ mengalami keriput namun tidak terlalu keriput hal tersebut terjadi pada semua ketebalan. Namun pada ketebalan $1 \mathrm{~mm}$ dan $2 \mathrm{~mm}$ mengalami penghitaman sedikit. Pada suhu $90{ }^{\circ} \mathrm{C}$ juga mengalami keriput namun tidak terlalu keriput hal tersebut terjadi pada semua ketebalan. Namun pada ketebalan $1 \mathrm{~mm}$ dan $2 \mathrm{~mm}$ mengalami penghitaman sedikit. Sedangkan pada suhu 120 ${ }^{\circ} \mathrm{C}$ dengan ketebalan $1 \mathrm{~mm}$ mengalami kekeriput yang sangat keriput. Namun pada ketebalan lainnya mengalami sedikit keriput. Untuk perubahan warna, pada suhu $120{ }^{\circ} \mathrm{C}$ mengalami sedikit hitam pada semua ketebalan

Tabel 2 memperlihatkan hasil organoleptik terhadap ubi jalar dengan suhu 70,90 dan $120^{\circ} \mathrm{C}$ pada ketebalan $1 \mathrm{~mm}, 2 \mathrm{~mm}, 3 \mathrm{~mm}, 4 \mathrm{~mm}$ dan 5 $\mathrm{mm}$. Pada suhu $70{ }^{\circ} \mathrm{C}$ seluruh bahan mengalami sedikit keriput dan perubahan warna menjadi sedikit hitam. Pada suhu $90^{\circ} \mathrm{C}$ seluruh bahan mengalami sangat keriput dan perubahan warna menjadi sangat hitam. Pada suhu $120^{\circ} \mathrm{C}$ bahan dengan ketebalan $1 \mathrm{~mm}$ dan $2 \mathrm{~mm}$ mengalami sangat keriput dan sangat hitam sedangkan pada bahan ketebalan $3 \mathrm{~mm}, 4 \mathrm{~mm}$ dan $5 \mathrm{~mm}$ mengalami sedikit keriput dan sedikit hitam. Pada suhu $90{ }^{\circ} \mathrm{C}$ mengalami sangat keriput dan sangat hitam kemungkinan dikarenakan bahan yang digunaka sebelumnya busuk namun tidak disadari oleh praktikan sehingga ketika dikeringkan perubahan warna menjadi hitam dan keriput.

\section{KESIMPULAN}

Kadar air ubi kayu terbaik pada suhu $90^{\circ} \mathrm{C}$ yaitu $54.367 \%$ dengan ketebalan $4 \mathrm{~mm}$ serta hasil laju pengeringan maksimalnya pada suhu $120^{\circ} \mathrm{C}$ yaitu $0.091 \mathrm{gram} /$ menit dengan ketebalan $5 \mathrm{~mm}$. Hasil uji organoleptik menunjukkan semua bahan pada suhu $120{ }^{\circ} \mathrm{C}$ mengalami penghitaman namun bahan pada suhu $70{ }^{\circ} \mathrm{C}$ dan $90^{\circ} \mathrm{C}$ dengan tebal 3, 4 dan $5 \mathrm{~mm}$ tidak mengalami penghitaman. Sedangkan pada ubi jalar, kadar air terbaik pada suhu $70{ }^{\circ} \mathrm{C}$ yaitu $66.397 \%$ dengan ketebalan $1 \mathrm{~mm}$ serta hasil laju pengeringan maksimalnya pada suhu $120{ }^{\circ} \mathrm{C}$ yaitu 0.077 gram/menit dengan ketebalan $5 \mathrm{~mm}$. Hasil uji 
organoleptik memperlihatkan semua bahan mengalami penghitaman dengan bahan yang paling hitam dialami pada bahan dengan perlakuan suhu $90^{\circ} \mathrm{C}$ dengan ketebalan $1 \mathrm{~mm}$.

\section{DAFTAR PUSTAKA}

Garayo, J., and R. Moreira, 2002. Vacuum frying of potato chips. Journal of Food Engineering 55:181-191.

Koswara, S. 2013. Teknologi Pengolahan UmbiUmbian Bagian 5: Pengolahan Ubi Jalar. Southeast Asian Food And Agricultural Science And Technology (Seafast) Center Research And Community Service Institution Bogor Agricultural University: Bogor

Kroikida, M.K., V. Oreopoulou, Z.B. Maroulis and D.Marinos-kouris, 2001. Colour changes during deep-fat frying. Journal of Food Engineering, 48:219-225.

Rohanah, A. 2006. Teknik Pengeringan (TEP421). Buku Ajar, Departemen Teknologi Pertanian Fakultas Pertanian USU 2006 : Medan.

Rukmana, R. 1997. Ubi Kayu, Budidaya dan Pasca Panen. Penerbit Kanisius (Anggota IKAPI) : Yogyakarta.

Suharto. 1991. Teknologi Pengawetan Pangan. PT RINEKA CIPTA : Jakarta

Veleșcu, I. 2013. Experimental Study Of Drying Behaviour Of Potato. Lucrări Ştiinţifice. Vol. 56.

Yahya, M., Fudholi, A., Hafizh, H. \& Sopian, K., 2016. Comparison of solar dryer and solarassisted heat pump dryer for cassava. Solar Energy. 136:606-613. 